\title{
The missionary role of mainstream Christianity: Towards a narrative paradigm for social integration of minorities in pluralistic post-apartheid South Africa
}

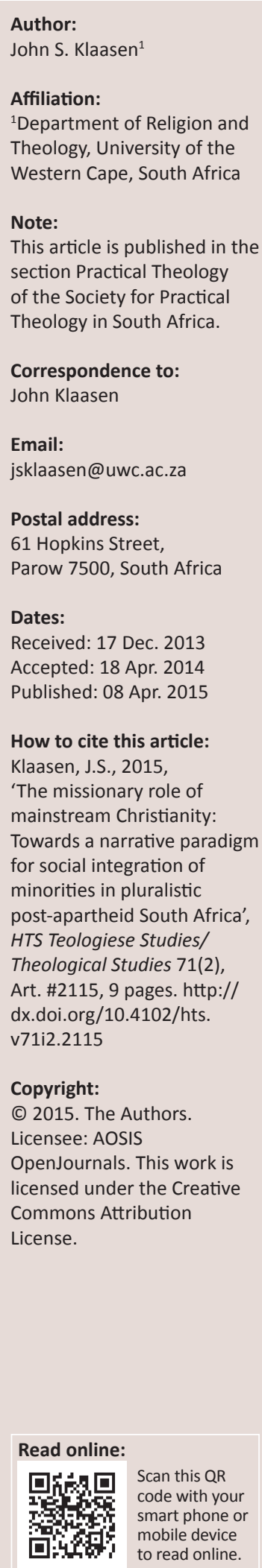

This article attempts to add to the existing approaches of practical theology and specifically to the missionary approaches of mainline churches towards immigrants. This is an attempt to enhance the mission amongst immigrants by critically engaging with the two approaches, namely: mainstream and margins and pillarization. Notwithstanding the important contributions that these two approaches make to tolerance, integration and cohesion of differences I seek to point out some serious limitations of the two approaches. These limitations include social coercion, co-option, relativism and loss of identity. Considering these limitations a third approach, the narrative approach, takes serious community, tradition and symbol for more effective mission amongst immigrants by mainline churches. Social cohesion, a more realistic reality and integrated communities are some of the consequences of this approach when doing missionary activities amongst immigrants.

\section{Introduction}

South Africa has experienced an unusually high influx of immigrants from other African countries in the last decade compared to the period between 1994 and 2001. The level of immigration from 1994-2001 could be attributed to scepticism and uncertainty about the transition from apartheid to democracy. According to Erasmus (2012:46) 'it is quite possible that the political climate played a role'. The influx from 2002 on the other hand can be attributed to the attraction of the peaceful transition to democracy and the stable conditions under which religious and cultural diversity exists. Advanced technological and economic growth and social development that South Africa has made under peaceful conditions compared to the majority of other African states also play a role in the increase of immigrants to South Africa. In the corresponding periods (late 1980s-2001) there has also been a decrease in the amount of Christians. South Africa has experienced a subsequent increase of Christians from 2001. This fluctuation in the numbers of Christians is largely attributed to the patterns in the black African population (SouthAfrica.info n.d.; Statistics South Africa n.d.).

The ratio of immigrants in the late twentieth century, worldwide, was one in every fifty persons (Erasmus 2012:45-46; see in particular Hendricks and Erasmus 2005). In South Africa, immigrants have increased from 4835 in 2001 to 6545 in 2002. However, in 2003 there has been a 39\% increase and in 2013 there were about 142800 documented 'foreigners' ('individuals who are not citizens') in South Africa out of a population of 51770560 million people. More than half (55.4\%) of the immigrants are from other parts of Africa (SouthAfrica.info n.d.; Statistics South Africa n.d.). Such a vast number of immigrants subsequently brought about many varied cultural, social, economic and especially religious practices. Amongst the immigrants the two dominant religions are Islam and Christianity, with the latter being by far in the majority. Whilst Islam has been a fairly homogeneous group, Christianity has been heterogeneous. Christian immigrants are from the mainstream (mainly Anglican, Reformed, Lutheran and Roman Catholic), Pentecostal and Charismatic traditions. These three traditions account for many varied religious and social practices.

Despite the peaceful transition from separate development to democracy and the co-existence of religions, there have been episodes of conflict that threatened the fragile social cohesion of the South African nation. In many ways immigration has resulted in - or at least contributed to conflict. Many violent confrontations can be attributed to foreign cultural and social practices. These cultural and social practices are not completely separated from religious practices, beliefs or persuasions. To this effect Mbiti (1975) reminds us that Africans are homo-religious. This is evident in how religious spaces and times are appropriated by immigrants. Buying big business premises, using technology, the prosperity gospel and having long services are aligned 
with the idea of the African person being homo-religious. Long services are not only divine encounters, but meals are shared, fellowship held and identity fostered. These exclusive practices threaten to slow down the progress that has been made towards social integration. Immigrants form communities of enclaves instead of being included in the broader South African society.

Immigration has contributed to the change in social patterns in a nation of communities in community. Immigrants from other parts of Africa form one of the most significant patterns of social mobility alongside those who have moved between the urban and rural areas, the rich and the vast majority of poor people, different cultural practices and diverse religious practices and doctrines.

This article is an attempt to critically engage the missionary role that mainstream Christianity can play to foster social cohesion amidst the influx of immigrants from other African countries. Mainstream Christianity could create space for migrants to form part of the Christian community through the retelling of the Christina narrative as an open narrative. When the Christian community takes on an open narrative form, its missionary role includes a projection of a truthful community to the world. In this way, this refers specifically to the Christian community and more generally to the societal community.

Scholarship in this research area has focussed primarily on imperialist domination and the tensions it creates with the varied South African cultures. Nieder-Heitmann, who headed the emerging Gospel and Our Culture network in South Africa, typically represents this strand of thought. Of South Africa he states:

As a modern state, it emerged out of a colonial history of 350 years, as diverse colonial, settler, and indigenous forces history vied for hegemony. It was not simply a matter of Western culture encountering an array of indigenous cultures; consecutive waves of disparate colonial forces also led to a struggle between competing variations of Western culture and Christendom. Within these, the gospel has been interpreted in various ways to accommodate a plurality of worldviews and interests. (Nieder-Heitmann 2003:178)

Modernism, post-modernism, rationalism, pluralism, relativism, liberalism and secularism are some of the phenomena that compete for superiority. It is my intention to show that immigration is a crucial phenomenon for the study of Christian mission in South Africa. More importantly, I hope that this article will add to the hermeneutical tools that undergirds the church's calling as faithfulness to the Missio Dei.

I will critically compare and contrast paradigms of the church's role for social integration. Integration refers to the inclusion of migrants as participants in the truthful narrative of Jesus Christ's birth, ministry, death and resurrection. Integration is not about passive recipients on the basis of the rules and laws of the powerful, but on the basis of vulnerable and active actors in a narrative that is relevant and ever life-giving. The two paradigms that will be analysed and critiqued are the mainstream and margins and pillarization. Finally, I will show how narrative can enhance the theology and practice of mission within mainstream Christianity. Because of the many social, cultural and political assumptions of the last twenty years that is evident in South Africa, my approach will be within the scope of practical theology, but drawing from the resources of those researchers whose research is within the sociology of religion (Davie 2004). When people are socially well positioned and in relative stable environments, they will seek corresponding religious communities. Gill (1996:345) indicates that Marx's famous dictum, 'religion is the opium of the people', resonates with the claim that religion influences society. My contention is that if Gill is correct in his claim, then mainstream Christianity will do effective mission when they contribute to socially integrated, peaceful environments and culturally sustained communities. Social cohesion is a much used phrase amongst communities such as in South Africa that has gone through major changes. Mainstream Christianity has a narrative that has a central message of reconciliation. The narrative forms the basis of the Christian understanding of integration and community is formative in being human.

\section{Mainstream and margin}

The first paradigm addresses mainstream Christianity's privilege role as the centre and immigrants as part of the margins or the periphery. This paradigm is identified in secularism of Western Europe (Martin) in which the former state-church (symbolically presented by the influence of the queen on the Anglican Church in Britain) or Christianity's ongoing influence on society (Poland and the Roman Catholic Church) still maintains a privileged position over new largely minority spiritualties and religions. This paradigm is well illustrated by the three catalysts used as illustrations (Davie 2013:138-184).

\section{Grace Davie's three catalysts}

Davie (2013) uses three catalysts in Britain, France and the Netherlands to illustrate the attempt of mainstream Christianity to include minorities and those on the margins into the centre. In the first case she uses the incidents of a controversial novel and a play with explicit sex scenes in a temple. The novel was publicised by Salman Rushdie, and entitled The satanic verses. The result of the publication of the novel drew angry outbursts, violent clashes and a declaration of a fatwa, in which Rushdie was declared guilty of blasphemy, by Ayatollah Khomeini. Rushdie was forced into seclusion. Many lives were lost in serious clashes, including a Japanese victim who translated the novel. The different responses from those in the West and the Muslim world to the publication and the consequences can be explained by the impact of the Enlightenment. Europeans and Christians who are nurtured in a post-Enlightenment climate divorce subject from object, whereas Muslims find it difficult to distinguish themselves from blasphemy. 
Another case involved the play, entitled Behzti, which was performed in Birmingham's Repertory Theatre, by a female Sikh playwright. In this play, incidents of sex and violence are displayed in a Sikh temple. The response to the play was similar to that of satanic verses. Peaceful protests turned into violent confrontations and resulted in the withdrawal of the play for safety reasons. It brought the discussion of minority religions and freedom of speech in cultural diverse, democratic dispensation as a serious part of the academic arena. The more important issue is whether the mainstream religion can ignore the minority religions. The reaction of the Queen and Baroness Uddin in the House of Lords (both from the established church and both calling for tolerance), are clear signs of tolerance in the wake of secularisation.

The second catalyst is the incident of three girls who wore Muslim headscarves to school in France. The result was that the three girls were expelled from attending school. This reaction by the state was a direct consequence of the emergence of both a secular ideology and a group of institutions through which the ideology is initiated, sustained and fostered. These institutions included educational organisations and the state departments. The parallels are also evident in the Catholic Church. The important question was why Christian and Jewish symbols have been tolerated in the post-war period.

This incident led to a new law in March 2005 in an already democratic nation based on a secular ideology. This meant that all religious symbols and indications of religious affiliations were banned from schools. In this case ideology typically enforces coercion towards a French state. This raises similar issues as in the British case. Issues such as what is public space and what is private space, what can and cannot be taken as religion, and is religion a threat to freedom become important in discourses such as religion and sociology (Davie 2013:165).

The third catalyst relates to the violent deaths of a prominent politician, Pim Fortuyn in 2002 and Theo van Gogh, a film producer in 2004. Fortuyn, a gay activist, campaigned successfully for a Dutch consensus through the promotion of 'liberal values with illiberalism, for example by excluding from society those who do not share the views of the majority (Davie 2013:179). Fortuyn was shot dead by an animal rights activist. Van Gogh was killed for his antiMuslim depictions by a Dutch-born Moroccan Muslim. This raised questions about the success of the essentially tolerant Dutch society. Both Fortuyn and Van Gogh campaigned for a consensus, and although the Dutch society has been characterised as a tolerant one, the exclusion of minorities had serious consequences. The Reformed churches have always had a privileged position as the established church amongst churches (Nieder-Heitmann 2003:365). The role of Reformed churches can be questioned. An additional issue to the former two catalysts is the ability of the Dutch society to accommodate a diverse population and especially diverse religious communities.
These catalysts should be viewed in light of the immigration integration policies. In Britain immigration legislation started as a political compromise based on race relations (1965) and progressed to multiculturalism (The Swann report, Education for all, in 1985) to a 'common sense of nationhood' (Secure borders, Safe Haven: Integration with Diversity in Modern Britain in 2002) (Schain 2010:213). The riots between 2001 and 2005 brought a shift from a nation consisting of 'communities of communities' to a nation of citizens with shared values.

According to Schain (2010):

Beginning on November 1, 2005, all applicants for naturalisation were required to pass a 'Life in the UK' examination, together with certification in the English language. Together with new citizen ceremonies that include a pledge of allegiance ... (p. 213)

This development of the immigration policy indicates the attempt by the state to integrate immigrants into the British nation through anti-discrimination, but with a reasonable control over practices in the public space. The Anglican Church has supported this way of integration by calling for tolerance towards other religions. This was evident in the queen's speech shortly after her visit to a Sikh temple.

In France, the political motivation for integration was different for immigrants from Europe (as a result of the world wars) and those of North Africa (during the 1960s). Whereas integration of Europeans was permanent, for Africans it was temporary with the intention of returning them home.

The result of two decades of riots since the 1980s was that 'various approaches to discrimination have become integral to policy on integration since 2000'. The Sarkozy law of 2003, which was more strictly implemented through legislation in 2007, required that those who wished to be naturalised must demonstrate knowledge of rights and duties of citizens, a contract of family unification with punishment for any violation and the completion of a two month course on French language and values (Schain 2010:209-210).

With regard to the Dutch community, two policies has been legislated in the Netherlands; one that forced asylum seekers to leave, irrespective of how long they have been in the country, and the second was an even more vigorous effort to instil Dutch values in immigrants (Davie 2013:180-181).

Three important issues remain uncompromisingly present in all three catalysts and in Europe at large. They are that immigrants must master the language of the country, that they must demonstrate knowledge and commitment of the values of the receiving country and have access to employment (Euractiv 2008).

The three catalysts are symptomatic of the immigrant integration policy in the European Union. In both Britain and France the margins and periphery were subordinated to the mainstream or nationalisation. In all three scenarios, religion 
(Anglican, Catholic and Dutch Reform) was withdrawn from the public space, although less in Britain than in France and the Netherlands. Even where religion had some influence, it was to enforce social control and nationalisation in line with immigration integration policies.

Mainstream Christianity in South Africa has a historical privileged position. Since the arrival of the first colonialists in 1602 and for the next 140 years, Christianity has been the only recognised faith and the Dutch Reformed Church, the only denomination who had a close association with the state. With the influence of English Puritanism in the Netherlands, the colony integrated divine election and covenant grace, practical piety and theocracy, with the ideal society in which whites were the chosen people (Nieder-Heitmann 2003:180-181).

Whilst Lutheranism and Scottish Presbyterianism were allowed to be practiced, it was the Anglican Church who enjoyed state privilege after the loss of control over the colony by the Dutch. For the next 150 years, with short breaks in between, 'colonial-Anglo Christendom' dominated the colony. This meant that the ideal society was characterised by the Enlightenment, urbanisation and industrialisation (Nieder-Heitmann 2003:187).

In 1948 with the political victory of the Afrikaners, the National Party established a vision for a 'volkstaat' by syncretising 'Afrikaner nationalism and Puritan-Reformed theocratic ideals' (Nieder-Heitmann 2003:187). The values of modernity and liberalism, including individual freedom, autonomous reason and equality, were replaced by that of the apartheid policy. This included separate development, the white race as the chosen people of God, and separation according to racial classification.

During the different periods of colonialism and apartheid rule mainstream Christianity has been influential in the form of state and church collaboration, official church and state partnership or from a historical alliance perspective.

The Immigration Act of 2002 has replaced the Act of 1983. The former came into being as a result of the new changes after the dawn of democracy. The 2002 act excluded the distinction between the different cultural groups in South Africa, but provides legislature and laws for the control of foreigners. Foreigners are those individuals who are not citizens of South Africa. Citizens of South Africa refer to those individuals who are South Africans through naturalisation or birth.

Whilst this act creates legal grounds for the unification of the South African nation, it creates clear divisions between those who are part of the 'in group' and part of the 'out group'. For example, foreigners who seek to enter South Africa must proof to have a much needed skill which is transferrable. South Africa also does not have the infrastructure and the resources to deal with the applications of foreigners to enter South Africa under legal means. This partly contributes to the high number of illegal foreigners in South Africa and serious and violent conflict between foreigners and citizens.

With regard to mainstream Christianity's missionary role of social integration, it has three major shortcomings. Firstly, coercion replaces mission as conversion is not necessarily a voluntary act, but because of the authority that is implicit in the centre. Persons obey authority through consensus and subsequently accept the value system to meet primary needs such as integration and secondary ones such as social and economic privileges.

Mainstream religion, whether in a favourable church-state relationship or as a historical influential institution, cause coercion when it does not supply the needs for spiritual and social integration of minority groups. Coercion can be uncritical co-option by state entities in the public sphere or public alliances with certain political ideologies. Cipriani (2002:35), for example, claims that Tocqueville could deduce that religion, the Catholic Church, could have a long lasting influence in America because it did not take sides with political parties.

Secondly, when mainstream Christianity attempts to integrate individuals or groups from a privileged position through syncretism, it raises a host of tensions such as attachments and detachments, continuity and discontinuity, family relations and societal obligations. The group is stripped of its identity, and, in order to survive it has to take on the dominant foreign identity. If these tensions are not managed and controlled, then conflict arises which can spill over into violence and sometimes wars.

Mainstream religions whose mission is mainstream-centred, deny minorities full integration through assuming one maximum, which is usually their own. In the British case, the queen's attempt to appeal for tolerance is clearly a way of demonstrating Anglicanism's influential tradition amidst increasing secularism.

A third weakness relates to Cipriani's analysis of Tocqueville's conclusion that religion, the Catholic Church, remains faithful to the Missio Dei when it resists co-option into political power. The further the church is separated from political alliance, the closer it is to the authority confirmed by Jesus Christ and passed on by the apostles to ecclesiastical offices. It is better to resist the authority over a few than to lose authority over the mass(es) (Cipriani 2002:34-35). This also relates to the prophetic role of the church and those who hold offices as priests and prophets. According to Gill (1996:36-45), whilst Weber differentiates between the priest as authoritatively linked to a church and a prophet linked to a sect, he does not deny that the church's mission includes the challenge of existing authority, including political authority when the authority of priesthood, the tradition and the canons of scripture are undermined. The church accepts the authority of God and obedience to God as an ethical duty of all Christians. 


\section{Mainstream Christian mission as pillarization}

Mainstream Christianity in the United States of America (USA) presents us with another paradigm for mission amidst social dissolution. The USA, as opposed to Western Europe, has a relatively high level of religiosity in both praxis and doctrine. One of the main factors to which this difference can be attributed is the movement from mainstream Protestantism to conservative forms of religion (Davie 2013:151-153). This difference explains the different theoretical frameworks for the study and explanations of religious trends in Western Europe and North America. This difference is to a lesser extent evident in Martin's (2005) attempt to place Protestantism and other religious movements in the USA in one of five paradigms of secularisation (Hamilton 1995:176). The work of Berger indicates this difference in a more significant way when he moves away from his earlier focus on secularisation to a more critical position in his later writings (Berger 1992, 1997; Davie 2013:333). In Western Europe secularisation is the main theoretical framework, whilst the Rational Choice Theory dominates the epistemological landscape in the USA.

Davie (2013) describes the Rational Choice Theory intelligently as having its roots about 200 years ago in the infancy stages of American independence:

Here there was no monopoly embodied in a state church, simply a quasi-public social space that no single group could dominate. All kinds of different groups or denominations emerged to fill the space, each of them utilizing particular religious markers as badges of identity. (p. 69)

The principles of the Rational Choice Theory includes: the maximising of gain with the least cost. In religious terms this means making voluntaristic choices and not to be compelled by monopolistic, ritualistic religious practices. Secondly, supply increases demand. This refers to the inference that availability of spaces, both private and public, for diverse religious persuasions increases religious activities (Davie 2013:70-71).

Mission within this theoretical approach is characterised by voluntarism, individualism and choice. The individual make a voluntaristic choice amongst the most profitable religion with the least losses. The emphasis is placed on choice rather than co-option and variety rather than the dominance of one religion. Whilst all religions are at least partly communitarian, the Rational Choice Theory assumes that the individual make the choice of community in a solid pluralistic setting. Voluntarism is possible because of the supply of many varied religious movements. Each of these movements has equal access to spaces that create awareness. This is unlike Western Europe, where space to exercise religious practices is limited.

Religions or Christian denominations do not have a mainstream religion to compete with and do not stand under the authority of a state church or even a church with a historical influence. Martin (2005) observes that:

[i]n the contemporary world, the USA provides a model and indeed an icon of the expansive pluralism which so widely influences global society and it is a model, allowing vigorous nationalism to coexist with almost infinite religious variety. This is because the idea of 'America', so constantly invoked alongside the invocation of God, is attached to very broad values, such as enlightened optimism, which were long ago detached from roots in specific Protestant institutions. (p. 160)

That mainstream Christianity in the USA is part of the pillarization or religious diversity is in part because it fosters multiculturalism. Multiculturalism has been mainly an attempt to provide the individual to make choices with the least possible losses. The idea of American citizenship with ethnic association has been a diversion from the coerciveness of the 1920s by most of the states in the period after world war two. The legislature passed in $1972^{1}$ was undoubtedly an attempt to integrate immigrants into the American way of life without stringent coercive compulsions. The act of 1990 opened the door for an annual intake of 55000 immigrants. Multilingualism, at least as far as the voting register was concerned, was also implemented in 1975 (Schain 2010:217-218).

Like Western Europe, the two world wars have resulted in increased mobility across the Atlantic and between Africa and the USA. This gave rise to an increase of crosscultural marriages and the establishment of the civil rights movement. Multiculturalism is a form of social and conflict control. Christianity adopted an interplay position between religion and culture. In other words, as multiculturalism was established, so religions and denominations were also given equal access to public space. Protestantism became no more than an equal amongst the equals.

The dawn of democracy and the liberal constitution of South Africa pose challenges for the claim of superiority by traditionally state-aligned churches. Mainstream Christianity can no longer claim superiority and do not enjoy state protection or preferences. The constitution makes provision for religion without giving priority to any one religion or Christian denomination.

Since 1994 mainstream Christianity had to reinterpret its missionary role in a democratic South Africa with one of the most liberal constitutions in the world. With no official state church and a flood of different religious practices brought by immigrants, mainstream Christianity finds itself amongst the many that make up a vibrant pluralistic society. This has also resulted in a steep decrease of membership of mainstream churches and paradoxically increases in other traditions, such as the Pentecostals and Evangelicals.

Two major shortcomings can be identified with pillarization. From an existential perspective, Gill (1996) warns that in

1.President Richard Nixon signed into law that $\$ 15$ million should be spent on ethnic heritage programmes that would include African Americans, Native Americans and other ethnic groups (Schain 2010:217) 
Britain church decline is not a result of a lack of supply. Gill says that an oversupply of church buildings resulted in astronomical costs, which could not be maintained by congregations. This economic crisis gave way to disillusionment amongst church membership (Davie 2013:85). In South Africa, church buildings are not in short supply and mainstream Christian denominations are selling church buildings to other denominations and businesses. There is also a clear decline of membership in mainstream Christianity.

Another contributor to the state of main Christianity is the mobility of the church membership. Both amongst church membership and from the city centre to the rural areas, mobility is increasing, which makes the viability of church buildings unpredictable. A typical example is found in the current situation of the three Anglican dioceses that constituted the Cape Town diocese up to seven years ago. The diocese of Table View, with the most urban parishes and subsequently the most financially viable, is in a financial crisis. The trend in this diocese is to cluster a once vibrant church community under the curacy of one clergyperson. False Bay and Saldanha Bay dioceses, which are mainly rural, have experienced an increase in the amount of stipendiary clergy. The diocese of Saldanha Bay has more stipendiary clergy now than at any other time in its short history. However, there is no evidence of an increase in membership.

From an epistemological perspective mainstream Christianity runs the risk to be a harbinger of secularisation. If Troeltsch ([1912] 1976) is right that the church is 'that type of organisation which is overwhelmingly conservative, and which to a certain extent accepts the secular order, and dominates the masses ...' then through 'a process of compromising and adaptation' (Cypriani 2002:124-125), it lends itself to be servant of irreligiosity.

Choices presuppose autonomy, and autonomy presupposes abstract reason. Christianity is about the community, and more specifically a specific community with a specific history. Reason, a pillar of secularism, used as in the Kantian categorical imperative, is abstract and presupposes that individuals is abstract atomic.

Choices are not made outside of the history of the community. The individual stands in a common history, and when decisions are made it is done through dialogue and critical engagement and not abstract reason. Pillarization assumes that the supply will enable choices and that, as long as the supply exceeds the demand, choices meet the beliefs and practices of church members.

Pillarization might increase the market, but it does not necessarily increase commitment in belief and practices. Belief and practices are closely connected and finds expression in worship and not abstract reason alone. Pillarization leads to the ultimacy of relativism. In a South African context the immigrant groups might remain outside of the mainstream because of the sacralising of their group. Pillarization stifles integration.

\section{Mainstream Christianity as narrative for integration of the periphery and minority}

With such serious weaknesses as found in the above two paradigms, mainstream Christianity can enhance its mission in light of the narrative of Jesus Christ and the Christian community. God, scripture, beliefs, tradition and the view of the universe is comprehended through participation in the narrative of Jesus Christ. Narrative is another way to do mission in a pluralistic South Africa. Narrative is used in many varied ways. To borrow a line from Robin Gill (1996:128), 'Differentiation has gone about as far as it can go. It is time for a new integration'.

Martin (2005:142) uses narrative as, 'not based on rationalization and bureaucracy, but rather on story and song, gesture and empowerment, image and embodiment, enthusiastic release and personal discipline'. Here Martin refers to metanarratives which have received critique or at least diversions from various phenomenological directions. Conradie (2008) for example refers to narrative:

as if on a palimpsest where one text is partially effaced to make room for writing another. The image of writing on a palimpsest also indicates that these are different versions of and perspectives of the same [hi] story, not different stories altogether. One may detect a number of layers of writing on this palimpsest. (p. 14)

\section{Lucie-Smith (2007) refers to narrative as:}

a particular story; it is inductive rather than deductive. The story it examines is found, or 'embodied', in a community's tradition, and is usually taken to sum up or encapsulate the community's belief about itself, the world and God. (p. 1)

Lucie-Smith (2007:188) then argues for 'the narrative that is open'.

Metanarratives could be referred to as the grand narrative against which all other narratives can be evaluated. Martin's (2005) definition of narrative can be put in that category. Conradie (2008), on the other hand, places all narratives as part of a grand narrative, in which each particularity is relative with universal significance. Lucie-Smith's (2007) narrative is a metanarrative that is open to that which is beyond, whether other narratives or an absolute.

Drawing from all three notions of narratives, I present an open-ended narrative which is closely associated with Lucie-Smith's (2007) open narrative, but does not claim the superior position of a metanarrative or grand narrative. An open-ended narrative is not the evaluative factor, nor is it part of a whole. Instead, open narrative is inviting, enriching and creating through both commonalities and differences. 


\section{Open-ended narrative}

When mainstream Christianity does mission as an openended narrative, it is inductive and through critical engagement and dialogue (by movement) gives a new interpretation of community, tradition (non-rational symbol) and experience (reflected experience) as its core facets.

Unlike both the mainstream and margins and pillarization paradigms, open-ended narrative includes differences as equal dialogue partner without co-option or coercion. A narrative paradigm tells a truthful story because it does not claim a superior reality that is limited by rationality, historical influence or state relations. It approaches reality as critical realism that regards truth claims as what is real.

Mainstream Christianity contributes to social integration of minority Christian communities and that of immigrants particularly, when it fosters integration of those communities with an openness that their contribution is as real as that which is offered.

\section{Community}

From an open-ended narrative approach, the self is not treated as an atomic, independent, autonomous individual. 'I refer to the formation of the self in relationships. The self is never in isolation, but as a social being develops through interaction' (Klaasen 2013:113). The self views life and what it means to be human not merely from facts and abstract theories, but also by affection, action and emotion.

The self is not completely autonomous (Kant) or subjected to the community (Mbiti), or autonomous at times and social at other times (Gyekye 1997). The self has meaning when in creative relationships with other selves. Theologically, this is illustrated by Tutu's notion of ubuntu. Ubuntu is well demonstrated by Battle (1997) when he concludes that selves are inter-dependent in an environment of vulnerability. To this effect he states that Tutu:

stresses the Christian definition of relationship, as opposed to other social forms of communalism, to define Ubuntu. Influenced deeply by Anglican spirituality, Tutu is able to overcome African philosophy's tendency to go to the opposite extreme of discounting individuals for the sake of community. For him, being properly related in a theological Ubuntu does not denigrate individuality. Instead it builds an interdependent community. (Battle 1997:42)

Self-determination is not denied, as Mbiti (1975) concludes, but it comes through deeper awareness than mere rationalisation. Self-determination involves relationships that are characterised by openness, trustworthiness and honesty. To this effect Tutu (2004) sums up relationships when he states that:

[t]he Bible places human beings at the centre of the divine enterprise as creatures of infinite worth and dignity independent of our work, our ability, or our success. We are each created by God, like God, for God. (p. 34)
Immigrants are never isolated strangers that are detached from the mainstream. The grounds for inclusion in community are that they are created in the likeness of God. Through relationships integration becomes a process of affirmation and development of our interdependence on each other.

Immigrants bring a part of the truthfulness of the Christian narrative that enriches mainstream Christianity in a reciprocal way. Both immigrants and those participating in mainstream Christian worship have a mutually enriching effect on each other. Both are agents of spiritual and social growth.

\section{Tradition}

The story of mainstream Christianity has a long history that needs reinterpretation and re-enactment for its truthfulness because it is a human attempt to re-enact a divine reality. Shils (who wrote one of the most comprehensive works on tradition) uses the definition of tradition that derives from 'traditum' (the mode of transferring ownership of private property in Roman law). 'Traditum' is:

Anything which is transmitted or handed down from the past to the present ... The decisive criteria is that, having been created through human actions, through thought and imagination, it is handed down from one generation to the next ... includes material objects, belief about all sorts of things, images of persons and events, practices and institutions. It includes buildings, monuments, landscapes, sculptures, paintings, books, tools, machines. (Shils 1981:12)

The past of the story is not just a meaningless reference point, but an integral part of the Missio Dei. It has relevance in the present and shapes the future. It crosses space and time and goes beyond mere abstract reason. Tradition is about dialogue with the authenticity of the past, engaging with the present and creating an awareness of the future. According to Klaasen (2013):

On the one hand, tradition is about shared history with events, persons and periods and, on the other, bringing deeper meanings to these aspects that form part of tradition through reason. (p. 114)

Tradition becomes the present through imagination, ascetics and institutions that open up truths for the whole community, both those who has passed on and those who share the story. To this end reality is not fixed with strict barriers, but it is in the making, always inviting and creating. The language of reality is not disembodied parts, but its metaphorical nature allows the contexts to inform the here and now.

Selves are not reduced to subjects, but are living, active organisms who are involved in truth and reality at the same time. To this effect Gill warns us that knowledge is not restricted to explicit knowledge, but implicit knowledge is vital to the comprehensive knowing of reality (Gill 1996:125).

Immigrants who share in the Christian story share a common past and through narrative find meaning in the present. 
They should not be strangers to the present, because, through active participation their past informs the present and reality becomes more real.

Implicit in such a narrative approach to mission is the voice that is given to immigrants in the face of voicelessness. Voicelessness, according to Kritzinger (2012:234), is 'fundamentally a question of power and influence. And it is important to remember that power is not a thing'. Quoting Whitehead and Whitehead (1984:152), he continues to claim that power is about interacting and relations between people.

Tradition invites immigrants to be fully participant in the interpretation of reality. In this way reality is not imposition but empowerment. The past of immigrants becomes authentic through a process of truth forming. Immigrants find a place of power for the past, by shaping the present and the future. Tradition does not deny continuity and does not impose a metanarrative.

\section{Symbols}

Symbols uncover the plot of the story which for both Lucie-Smith (2007:193) and Conradie (2008:27) has cosmic significance. Using the Passion of Christ in this way, Lucie-Smith (2007:193) interprets the Passion as the old dispensation has passed away and the new one has come'. Weber's interactionist approach and Parsons's action theory resonates with Lucie-Smith's use of symbols when their two theoretical frameworks challenge the mechanical model of early natural science (Gill 1996:124). In these approaches of Weber and Parsons, feelings are important factors when the plot is unveiled. The question about the feelings of immigrants opens up a significant level of the plot and in the context of the open-ended Christian narrative uncovers layers of the story that enriches a common understanding of the story.

Gill (1996:126-128) mentions three points about symbols that are relevant for the inclusion of immigrants into mainstream Christianity. Firstly, it is a tool of hermeneutics. It questions what reality is and encourages openness to our sense of reality. Christian symbols entail critical reflection and dialogue. Dialogue is about participation in a critical reality that opens up the fixed, ultimate reality. Secondly, it has meaning by participation or, as Polanyi puts it, by 'dwelling in it'. Christian symbols are a means of welcoming those who are different. Immigrants participate in all aspects of the life of the community. This includes prayer, worship, biblical reflection, vestries and missionary activities. Thirdly, symbols speak to those inside and outside the group. The practices of immigrants do not have to be a barrier to the potential and the identity of the community. Differences are a force of growth and not necessarily enclavement. Confrontation does not have to lead to conflict, but can bring about a greater sense of what it means to be made in the image and likeness of God.

A narrative approach to mission is more than orthodoxy. Mainstream Christianity needs to consider the church's call as faithfulness to the Missio Dei. Coercion, dissolution and syncretism are symptomatic of the mainstream and margins and pillarization approaches to mission. An open-ended narrative does not claim absolute universality, or relativism, but through critical dialogue invites those outside as equal members of the community. Open-ended narrative is interested in (dialogue) movement and orthopraxis rather than orthodoxy, critical realism rather than ultimate reality (mainstream and margins) or ultimate relative reality (pillarization).

\section{Conclusion}

This article is an attempt to contribute to the missionary role of mainstream Christianity in pluralistic post-apartheid South Africa. It presents a critical discussion of two models, mainstream and margins and pillarization. Some weaknesses of the two approaches, such as social coercion, co-option, the loss of identity and lack of commitment have been pointed out. A third approach is then presented, an open narrative approach, which is characterised by community, tradition and symbols is presented as a more effective approach as missionary role by mainstream Christianity amongst migrants from other African countries.

\section{Acknowledgements Competing interests}

The author declares that he has no financial or personal relationship(s) that may have inappropriately influenced him in writing this article.

\section{References}

Battle, M., 1997, Reconciliation: The ubuntu theology of Desmond Tutu, The Pilgrim Press, Ohio.

Berger, P., 1992, A far glory: The quest for faith in an age of credibility, Free Press: New York.

Berger, P., 1997, Redeeming laughter: The comic dimension of human experience, Aldine de Gruyter: Hawthorne, New York. http://dx.doi.org/10.1515/9783110810660

Cipriani, R., 2002, Sociology of religion: An historical introduction, Aldine De Gruyter, New York.

Conradie, E., 2008, 'The earth in God's economy: Reflections on the narrative of God's work', Scriptura 97, 13-36. http://dx.doi.org/10.7833/97-0-711

Davie, G., 2004, 'Creating an agenda in the sociology of religion: Common sources/ different pathways', Sociology of religion 65(4), 323-340. http://dx.doi. org/10.2307/3712317

Davie, G., 2013, The sociology of religion: A critical agenda, SAGE Publications, London.

Erasmus, J, 2012, 'Religious demographics in post-apartheid South Africa Implications for social welfare', in I. Swart, A. Gouws, P. Petterssen, J. Erasmus, F. Bosman (eds.), Welfare religion and gender in past-apartheid South Africa: Fonstructing a South-North dialogue, SUN Press, Stellenbosch.
Consthen

Euractiv, 2008, Hompage, viewed n.d., from http://www.euractiv.com

Gill, R. (ed.), 1996, Theology and sociology: A reader, Cassell, London.

Gyekye, K., 1997, Tradition and modernity: Philosophical reflections on the African experience, Oxford University Publishers, New York. http://dx.doi.org/10.1093/ac prof:0so/9780195112252.001.0001

Hamilton, M.B, 1995, The sociology of religion: Theoretical and comparative perspectives, Routledge, London.

Hendricks, H.J. \& Erasmus, J.C., 2005, 'Religion in South Africa: The 2001 population census data', Journal of Theology for Southern Africa 121, 88-111.

Klaasen, J.S., 2013, 'Open-ended narrative and moral formation', Acta Theologica 32(2), 103-117.

Kritzinger, K., 2012, 'Overcoming theological voicelessness in the new millennium', Missionalia 40(3), 233-250.

Lucie-Smith, A., 2007, Narrative theology and moral theology: The infinite horizon, Ashgate Publishers Limited, Hampshire. 
Martin, D., 2005, On secularization: Towards a revised general theory, Ashgate Publishing Limited, Hants.

Mbiti, J.S., 1975, Introduction to African religion, Heinemann Books, London.

Nieder-Heitmann, J.H., 2003, 'The missionary challenge of Christendom and modernity in South Africa: A Dutch reformed account', International review of mission XC11(365), 178-191. http://dx.doi.org/10.1111/j.1758-6631.2003. tb00393.x

Schain, M.A., 2010, 'Managing difference: Immigrant integration policy in France, Britain, and the United States', Social research 77(1), Spring, 205-236.
Shils, E., 1981, Tradition, Faber and Faber, London.

SouthAfrica.info n.d., Homepage, viewed n.d., from http://www.southafrica.info

Statistics South Africa n.d., Home, viewed n.d., from http://beta2.statssa.gov.za

Troeltsch, E. [1912] 1976, The social teaching of the Christian churches, University of Chicago Press, Chicago.

Tutu, D., 2004, God has a dream: A vision of hope for our time, Random House, London.

Whitehead, E.E. \& Whitehead, J.D., 1984, Seasons of strength: New visions of adult Christian maturing, Doubleday Garden City, New York. 